\title{
Discrimination of habitat use between two sympatric species of mullets, Mugil curema and Mugil liza (Mugiliformes: Mugilidae) in the rio Tramandaí Estuary, determined by otolith chemistry
}

\author{
Ana C. G. Mai, Mauricio L. dos Santos, Valéria M. Lemos and João P. Vieira
}

Two sympatric species of marine mullets, Mugil curema and M. liza, use the rio Tramandaí Estuary as nursing grounds. When two closely related species are sympatric, various mechanisms may permit their coexistence, including spatial or temporal segregation that results in the divergent use of the resources for which they compete. To investigate the spatial segregation, we used otolith chemistry inferred through laser ablation-inductively coupled plasma mass spectrometry. Our results indicate that in the rio Tramandaí Estuary, M. curema is associated with high salinity waters and can be classified as a Marine Migrant in the Marine Estuarine-opportunist subcategory. Mugil liza is associated with lower salinity and can be classified as a Marine Migrant in the Estuarine Dependent subcategory. The intra-specific variation in estuarine habitat use indicates that the migratory behaviors in mullets are far more complex than previously known.

Keywords: Estuarine use, LA-ICPMS, Marine migrant, Migratory behavior, Otolith elemental fingerprint.

Duas espécies de tainha simpátricas, Mugil curema e M. liza, usam o estuário do Rio Tramandaí como zona de berçário. Quando espécies do mesmo gênero são simpátricas, vários mecanismos podem permitir sua coexistência, incluindo segregação espacial ou temporal que resultam no uso distinto dos recursos pelos quais elas competem. Para investigar a segregação espacial nós usamos a análise de elementos químicos em otólitos inferidos por espectrometria de massas através de plasma indutivamente acoplado com amostras extraídas a laser (LA-ICPMS). Mugil curema está associada a águas de alta salinidade podendo ser classificada como Marinho Migrante sub-categoria Marinha estuarina-oportunista. Mugil liza está associada a águas menos salinas, devendo ser classificada como Marinha Migrante sub-categoria Estuarina Dependente. A variação intraespecífica no uso do habitat estuarino indica um comportamento migratório mais complexo que o previsto em tainhas.

Palavras-chave: Assinatura química no otólito, Comportamento migratório, LA-ICPMS, Marinho migrante, Uso do estuário.

\section{Introduction}

Eight congeneric species of mullets inhabit the coast of South America: Mugil brevirostris (Ribeiro, 1915); M. curema Valenciennes, 1836; M. curvidens Valenciennes, 1836; M. incilis Hancock, 1830; M. margaritae Menezes, Nirchio, Oliveira \& Ramirez, 2015; M. rubrioculus Harrison, Nirchio, Oliveira, Ron \& Gavíria, 2007; M. trichodon Poey, 1875; and Mugil liza Valenciennes, 1836 (Menezes et al., 2015). In southern Brazilian estuaries, the juveniles of $M$. curema and M. liza occur in large numbers and M. brevirostris occurs in lower numbers (Vieira, 1991; Ramos, Vieira, 2001).

Mugil curema and M. liza are total spawners that reproduce in oceanic areas on the continental shelf (Ibáñez-Aguirre, Gallardo-Cabello, 2004; Silva, 2007; Fernandez, Dias, 2013; Lemos et al., 2014). After reproduction, the juveniles of both species move toward the surf-zone and recruit into lagoons and estuaries, where they spend most of their life cycle (Blaber, Blaber, 1980; Vieira, 1991; Ibáñez-Aguirre, 1993; Albieri et al., 2010). Therefore, mullets are generally assumed to be catadromous, migrating from estuaries to offshore for spawning (Silva, 1980). Nevertheless, recent studies have demonstrated high intra-specific variability in the migration patterns among several distinct species of mullets (Chang et al., 2004; Chang, Iizuka, 2012; IbáñezAguirre et al., 2012; Wang, 2014; Avigliano et al., 2015).

When two distinctive related species are sympatric, various mechanisms may permit their coexistence, including spatial or temporal segregation that results in the divergent use of the resources for which they compete (IbáñezAguirre, 1993; Albieri et al., 2010). In this study, we used otolith chemistry to discriminate the habitat use between two of the tree species of mullet that occur in the rio Tramandaí

Instituto de Oceanografia, Universidade Federal do Rio Grande, Av. Itália, km 8, 96203-900 Rio Grande, RS, Brazil. (ACGM) anacecilia_mai@yahoo.com.br, Dhttps://orcid.org/0000-0002-3172-1359 (corresponding author), (MLS) mlang.oceano@gmail.com, (VML) vavadeleom@yahoo.com.br, (JPV) vieira@mikrus.com.br 
Estuary: M. curema and M. liza. The differences in the depositional patterns of strontium $(\mathrm{Sr})$ and barium $(\mathrm{Ba})$ in the otoliths of fishes offer a tool to reveal different habitat uses of diadromous fishes (Gillanders, 2005; Walther, Limburg, 2012).

In this study, we test the hypothesis that the habitat uses of $M$. curema and M. liza differ within the same estuary. To test this hypothesis, we used two different approaches: first the concentration ratios of $\mathrm{Sr}: \mathrm{Ca}$ and $\mathrm{Ba}: \mathrm{Ca}$ at the cores and edges of otoliths were compared between species using the Mann-Whitney U test; next, the entire otolith readings of each specimen were visually compared throughout the life stages.

\section{Material and Methods}

We analyzed 23 specimens of $M$. curema (300 to 370 $\mathrm{mm}$ in TL) and 23 specimens of M. liza (320 to $490 \mathrm{~mm}$ in TL). The specimens were captured by artisanal fishermen between June 2014 and August 2014 in the rio Tramandai Estuary, Rio Grande do Sul, Brazil. The rio Tramandaí Estuary drains an area of $2,700 \mathrm{~km}^{2}$ and consists of 30 lagoons connected by channels flowing to the Atlantic Ocean $\left(29^{\circ} 18^{\prime}\right.$ to $30^{\circ} 26^{\prime} \mathrm{S}, 4^{\circ} 45^{\prime}$ to $50^{\circ} 34^{\prime} \mathrm{W}$; Fig. 1). Only two of these lagoons, Tramandaí and Armazém, have daily salinity fluctuations, and the salinity varies from 0 to 11 in the estuary (Kapusta et al., 2006). Voucher specimens of $M$. curema (FURG 2872, four specimens) and M. liza (FURG 2817, two specimens) that were collected during the same events were deposited in the Coleção de Peixes da Universidade Federal do Rio Grande.

The left sagittae otoliths were embedded in crystal polyester resin, and transverse sections were made through the core using a low-speed, diamond blade Isomet saw (Wang, 2014; Avigliano et al., 2015). Thin sections with 0.4 $\mathrm{mm}$ width were mounted onto glass slides with cyanoacrylic glue. Prior to laser ablation inductively coupled plasma mass spectrometry analysis, otolith surfaces were polished with silicon carbide paper (No. 8000), washed with ultrapure DI water (Milli-Q, Millipore, Bedford, USA), sonicated for 5 minutes, and rinsed three times with ultrapure water. The slides were then dried in a laminar flow cabinet before analysis.

Laser ablation-inductively coupled plasma mass spectrometry (LA-ICPMS) was used to quantify the concentrations of $\mathrm{Ca}^{43}, \mathrm{Sr}^{86}$, and $\mathrm{Ba}^{137}$ with a PerkinElmer DRC-e ICPMS coupled to a New Wave Nd-YAG 193$\mathrm{nm}$ laser (Electro Scientific Industries) at the Instituto de Geociências da Universidade de São Paulo. The laser was operated at a pulse frequency of $10 \mathrm{~Hz}$, a scan speed of 30 $\mu \mathrm{m} / \mathrm{s}$, and energy outputs of 10 and $12 \mathrm{~J} / \mathrm{cm}^{2}$ per pulse. Under these conditions, the crater width was approximately $30 \mu \mathrm{m}$. The ablated material was conducted through a Teflon-coated tube into the ICP-MS using argon as a carrier gas. After each otolith ablation, the background intensity was measured for 60 s. Strontium and calcium counts per second (cps) were subtracted from the background level, and element:Ca ratios were then calculated for all otoliths. The ICP-MS had been previously optimized for daily performance, with maximum analyte intensities and minimum interferences determined using oxides and double charged ions. The otolith samples were read in random order. A certified glass reference standard National Institute of Standards and Technology NIST 612 was run at the start and end of each session and after every 10 otoliths to correct for mass bias and machine

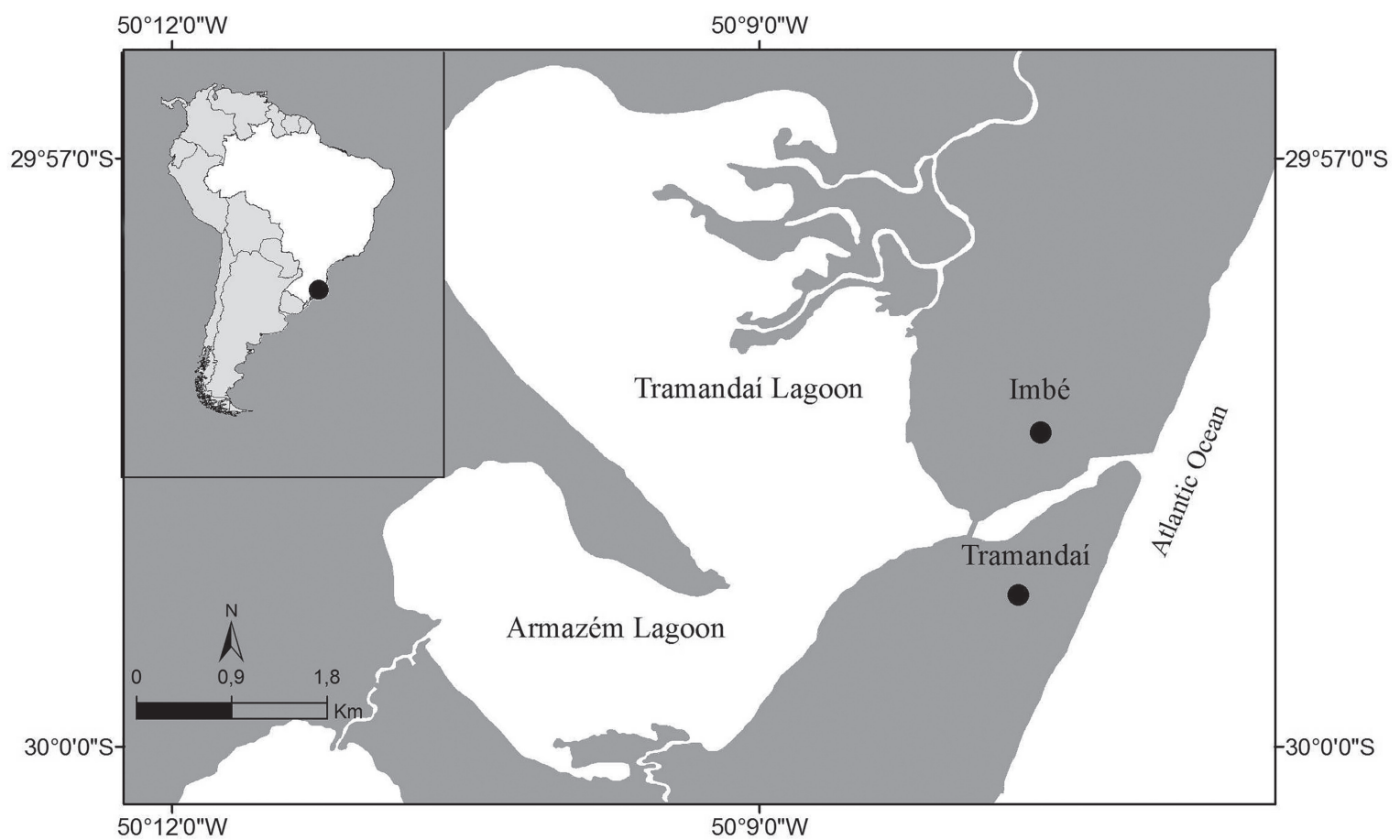

Fig. 1. Maps showing the sampled area, Southwest Atlantic, rio Tramandaí Estuary. 
drift. Estimates of external precision (\% relative standard deviation) were assessed by measurements of a calcium carbonate certified reference material MACS-3 (United States Geological Survey) and were as follows: $5.7 \%\left({ }^{86} \mathrm{Sr}\right)$, and $3.2 \%\left({ }^{137} \mathrm{Ba}\right)$. Data reduction, including background corrections, conversion of mass count data to concentrations (ppm) and limits of detection were all performed for each sample via Glitter software GEMOC, Macquarie University.

The transects of the otoliths from the nucleus to edge were used to analyze the elemental concentrations through the entire life history of each individual. The chemical signatures of the first 20 reads of the otolith core were used to represent the physical-chemical properties of the birthplace (core), and the last 20 reads of the edge were used to represent the most recently deposited material. For these comparisons, we applied the Mann-Whitney U test (Avigliano et al., 2015).

The habitat use profiles were visually interpreted and based on two assumptions: first, $\mathrm{Ba}$ :Ca ratios in the otolith below the $0.5 \mu \mathrm{mol} . \mathrm{mol}^{-1}$ threshold indicate that the fish was in a marine habitat. This assumption considered the upper concentration limit of the $\mathrm{Ba}$ :Ca ratio found in the cores of otoliths of both species, and the fact that they both spawn at sea (Ibáñez-Aguirre, Gallardo-Cabello, 2004; Lemos et al., 2014); second, $\mathrm{Ba}: \mathrm{Ca}$ ratios above the $1.8 \mu \mathrm{mol}_{\mathrm{mol}}{ }^{-}$ ${ }^{1}$ threshold suggest that the fish spent time in freshwater habitat. This assumption was validated using ten specimens of M. liza sampled from the limnetic zone of the Laguna dos Patos, which is located $100 \mathrm{~km}$ from the study area.

\section{Results}

The Sr:Ca ratios in the otolith cores were similar in both species: Mugil curema $1.91 \pm 1.55 \mathrm{mmol}^{\mathrm{mol}}{ }^{-1}$, Mugil liza

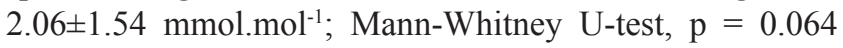
(Fig. 2). These high values of $\mathrm{Sr}$ in the core provide evidence that both species spawn in marine waters. Moreover, the $\mathrm{Sr}: \mathrm{Ca}$ ratio at the edge of otoliths was significantly higher in M. curema than M. liza $\left(2.6 \pm 2.9\right.$ and $1.7 \pm 1.1 \mathrm{mmol}^{\mathrm{mol}}{ }^{-1}$, respectively) (Mann-Whitney U-test, $\mathrm{p}<0.05$ ). The $\mathrm{Ba}: \mathrm{Ca}$ ratios in the otolith cores and edges were significantly lower in $M$. curema (core $0.21 \pm 0.20 \mu \mathrm{mol}_{\mathrm{mol}}{ }^{-1}$, edge $0.24 \pm 0.25$ $\mu$ mol.mol ${ }^{-1}$ ) (Mann-Whitney U-test, $\mathrm{p}<0.05$ for both) than in $M$. liza (core $0.53 \pm 0.48 \mu \mathrm{mol}^{\mathrm{mol}}{ }^{-1}$, edge $1.58 \pm 1.23$ $\mu$ mol. $\left.\mathrm{mol}^{-1}\right)$.

The cross-otolith lifetime profiles derived from the $\mathrm{Sr}: \mathrm{Ca}$ and $\mathrm{Ba}$ :Ca ratios showed differences in habitat use within $M$. curema and M. liza individually (Figs. 3-4). Nevertheless, the Sr:Ca ratios did not show a pattern that would aid in our interpretation of estuarine habitat use for either species (Figs. 3-4).

Mugil curema has four patterns of habitat use. In 27\% of the specimens, low Ba:Ca values throughout the entire section indicate that the specimens probably spent their entire lives in high-salinity water (Fig. 5a). In 30\% of the specimens, the high $\mathrm{Ba}: \mathrm{Ca}$ values over short periods indicate sporadic entries into brackish waters (Fig. 5b). In the third pattern, $13 \%$ of the specimens have episodes of very high $\mathrm{Ba}$ :Ca ratios, suggesting the use fresh water for a short period of time (Fig. 5c). Finally, 30\% of the specimens have high $\mathrm{Ba}: \mathrm{Ca}$ values over long periods, which indicates the use of brackish waters for longer periods of time with incursions into fresh water for short time periods (Fig. 5d). As $M$. curema exhibits partial migration, the contingents show different patterns of habitat use.

Mugil liza showed two patterns of habitat use. The first group included individuals that had $\mathrm{Ba}: \mathrm{Ca}$ ratios within the brackish water range, which indicates the use of estuarine waters during most of their life cycle; the second group includes $56.5 \%$ of the individuals that had episodes of very high $\mathrm{Ba}: \mathrm{Ca}$ ratios, which indicates the use of both brackish and freshwater habitats throughout their life (Figs. 6a-b, respectively). These multiple contingents of Mugil liza showed different uses of the estuary, but the species appeared to be more dependent on the estuary.
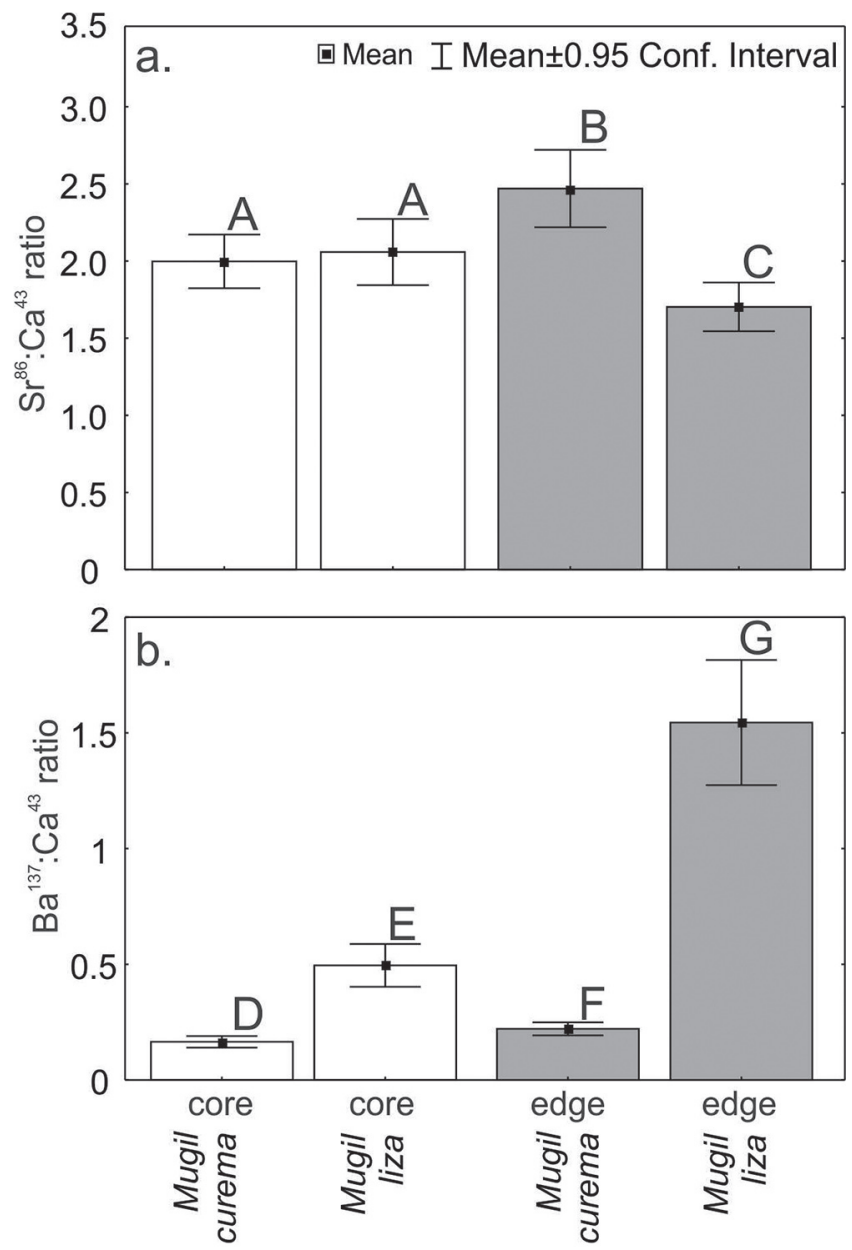

Fig. 2. Means and standard deviations (SD) of (a) $\mathrm{Sr}^{86}: \mathrm{Ca}^{43}$ $\left(\mathrm{mmol} \cdot \mathrm{mol}^{-1}\right.$ ); and (b) $\mathrm{Ba}^{137}: \mathrm{Ca}^{43}$ ratio $\left(\mu \mathrm{mol}^{\mathrm{mol}}{ }^{-1}\right)$ in otoliths of the inner 20 measurements (core) and the outer 20 measurements (edge) of Mugil curema and M. liza caught in the Tramandaí River Estuary, Brazil. Different letters within a spruce stand denote significant differences between species (Mann-Whitney U test, $\mathrm{p}<0.05$ ). 


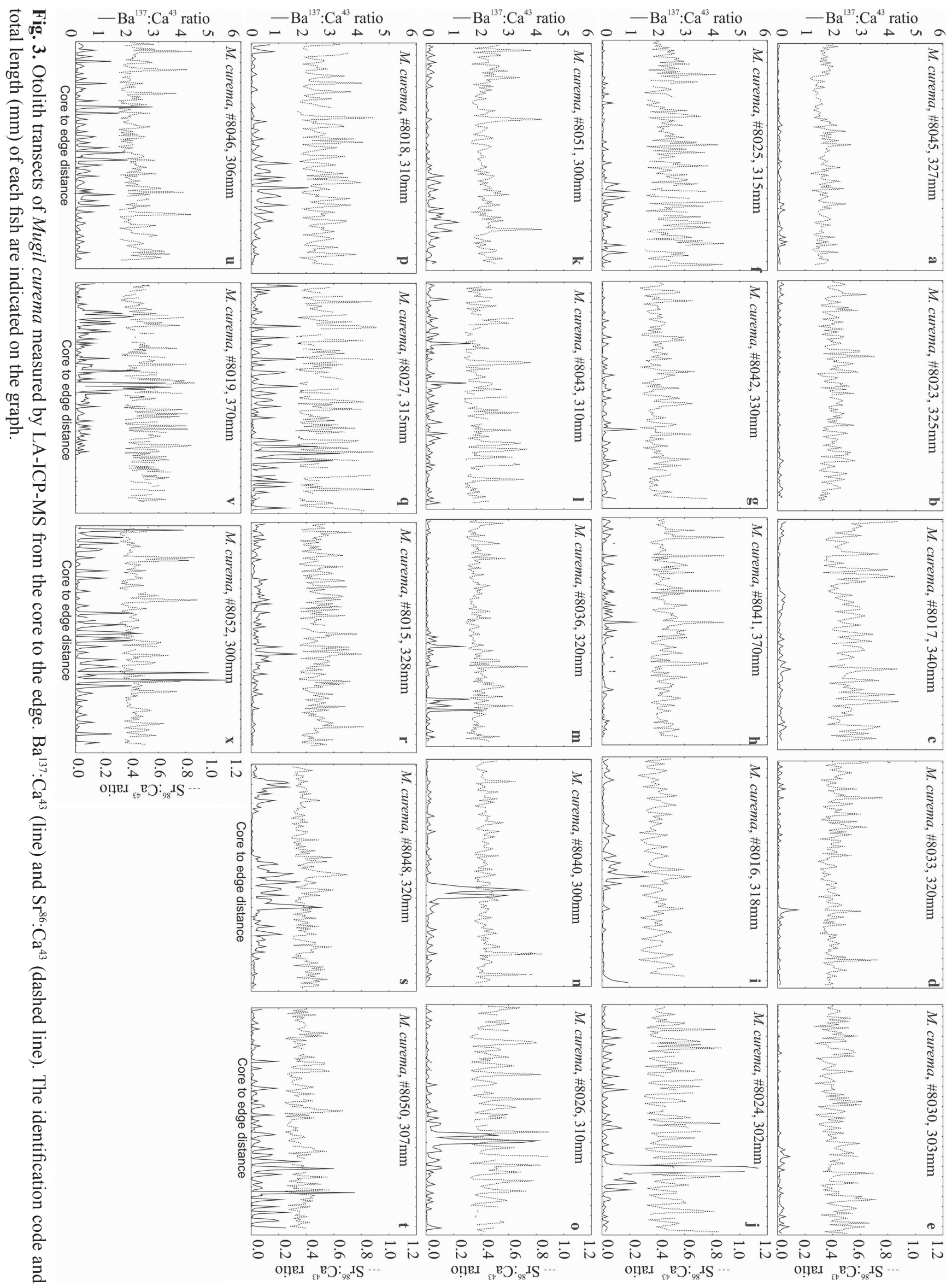



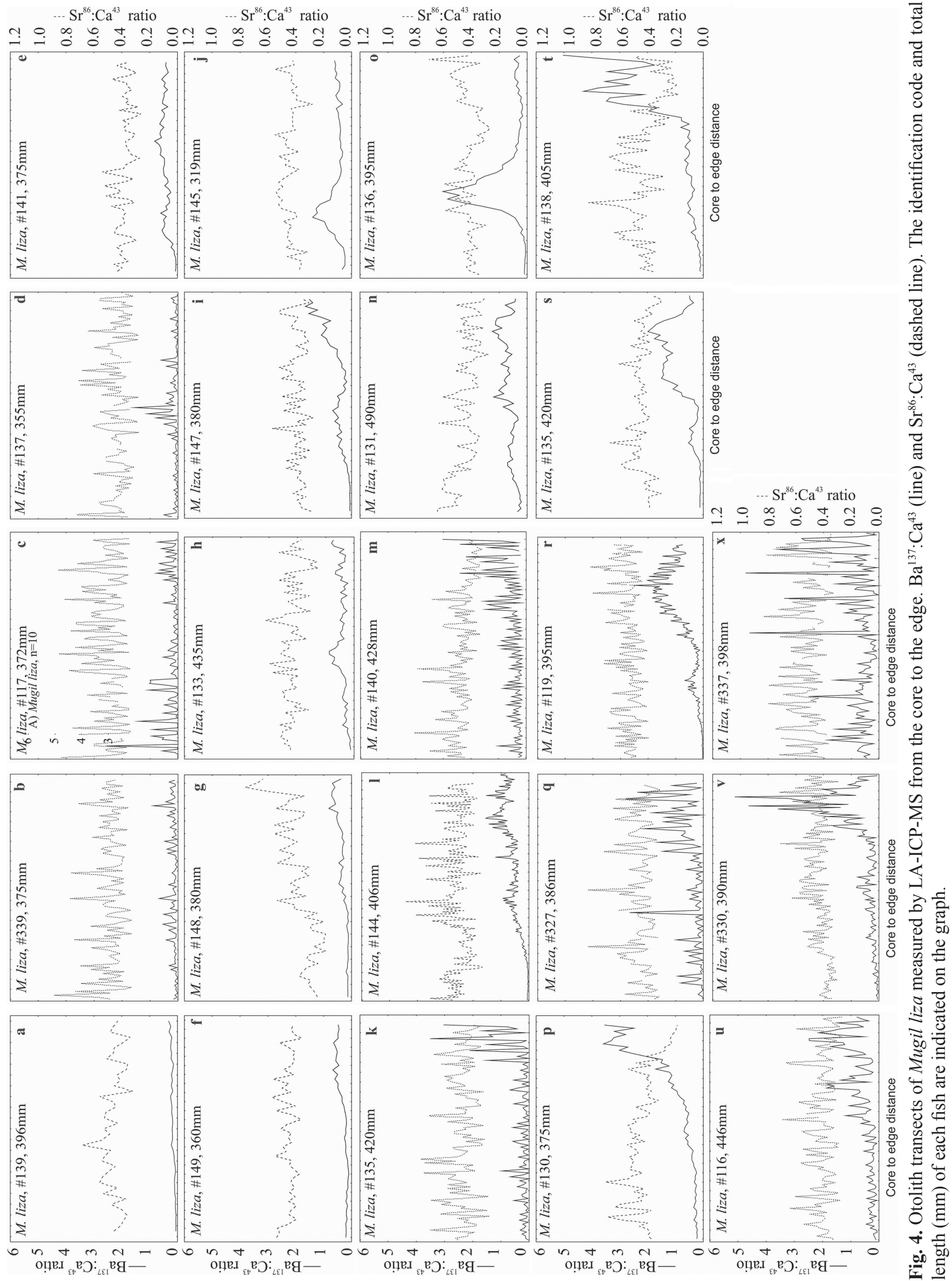

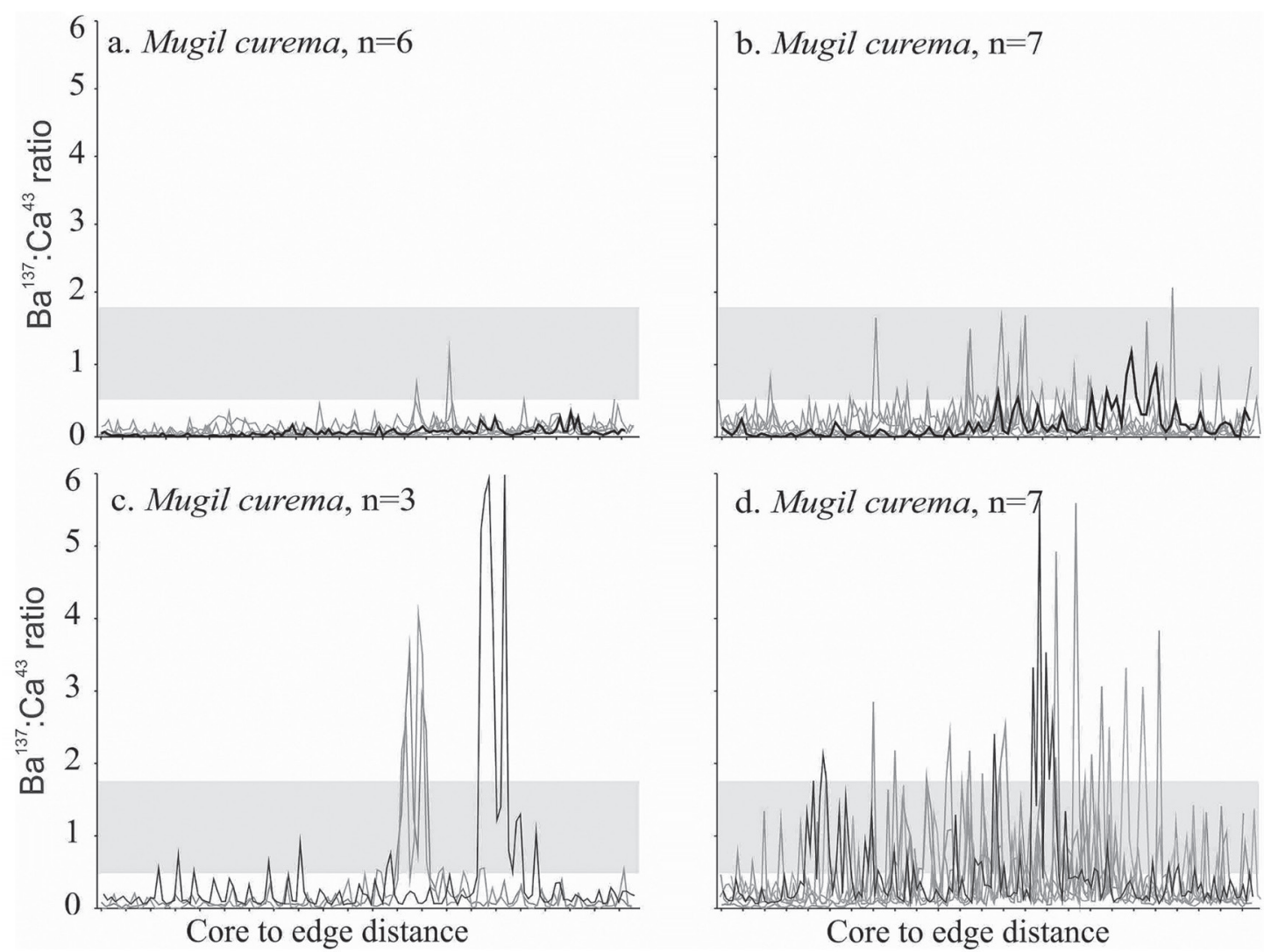

Fig. 5. Mugil curema. $\mathrm{Ba}^{137}: \mathrm{Ca}^{43}$ variations $\left(\mu \mathrm{mol} \cdot \mathrm{mol}^{-1}\right)$ along transects from the core to the edge of the otolith. Individuals were from the rio Tramandaí Estuary, Brazil. The horizontal gray bands between the $\mathrm{Ba}^{137}: \mathrm{Ca}^{43}$ ratios of 0.05 and 0.18 indicate migration in brackish waters (see M\&M).
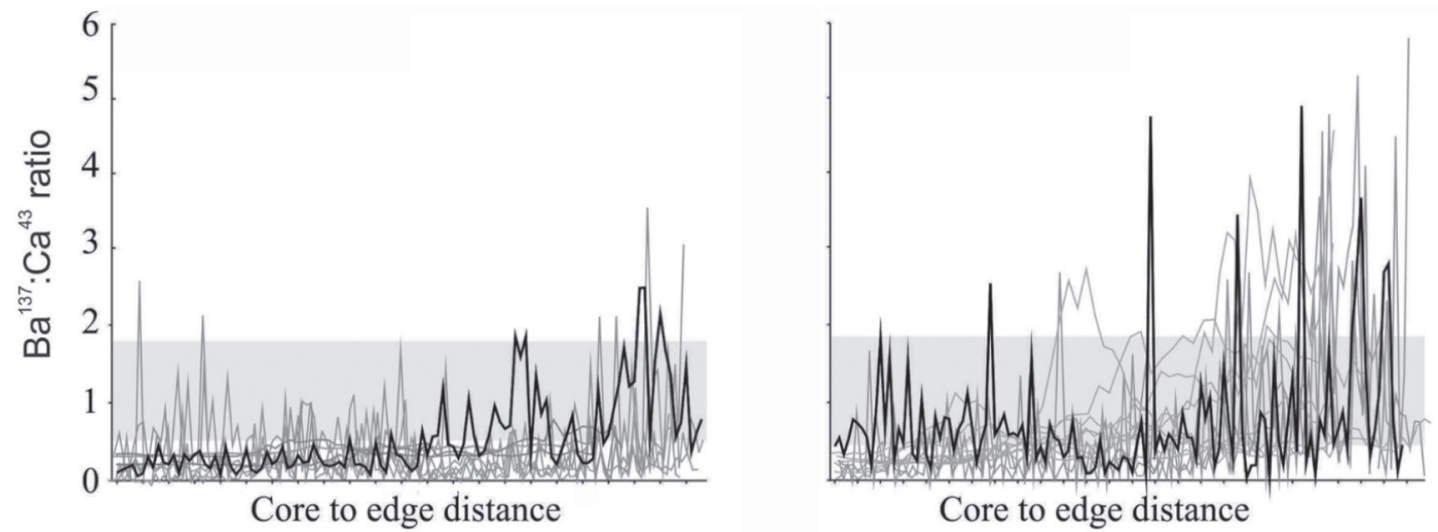

Core to edge distance

Fig. 6. Mugil liza. $\mathrm{Ba}^{137}: \mathrm{Ca}^{43}$ variations $\left(\mu \mathrm{mol} \mathrm{mol}^{-1}\right)$ along transects from the core to the edge of the otolith. Individuals were from the rio Tramandaí Estuary, Brazil. The horizontal gray bands between the $\mathrm{Ba}^{137}: \mathrm{Ca}^{43}$ ratios of 0.05 and 0.18 indicate migration in brackish waters (see M\&M).

\section{Discussion}

The Sr:Ca and $\mathrm{Ba}: \mathrm{Ca}$ ratios at the core otolith regions in both $M$. curema and $M$. liza indicate that these two species spawn in marine waters. However, the reproductive periods of $M$. curema and $M$. liza are different, suggesting that spawning occurs in distinct environmental conditions. In southeastern Brazil, Mugil curema spawns between October and April with two annual peaks in April and November
(Fernandez, Dias, 2013). Mugil liza spawns between April and July with a single peak in June (Lemos et al., 2014). Indeed, the abundances of juveniles of both species exhibit seasonal differences in the estuaries of southern Brazil. While the juveniles of $M$. liza are more abundant in the winter, those of M. curema are more abundant in the summer (Vieira, 1991; Ramos, Vieira, 2001). The different spawning periods associated with warmer waters for M. curema and cooler waters for M. liza act as a mechanism to reduce the 
competition among juveniles of these two species after recruitment in the estuary (Vieira, 1991; Albieri, Araújo, 2010). The winter in southern Brazil is characterized by an increase in precipitation, which consequently increases the river and estuarine runoff and reduces the salinities in the estuaries and adjacent coastal areas. On the other hand, the reduced precipitation and the predominance of tropical waters in the coastal region during the summer increase the salinities in the estuaries (Ciotti et al., 1995; Soares, Möller, 2001; Möller et al., 2008).

Only the $\mathrm{Ba}$ :Ca ratio was used to reconstruct the habitat use profiles of the individuals because the $\mathrm{Sr}: \mathrm{Ca}$ ratio fluctuated among individuals of the same species; therefore, a directional trend throughout the otolith transect was not clear. In Marine Migrant species that experience intermediate salinity of 20$35 \mathrm{ppm}$, the analysis of the Sr:Ca ratio has limited ability to distinguish long periods of residence in fully marine or mid-estuarine habitats (Kraus, Secor, 2004; Chang et al., 2004; Walther, Limburg, 2012). The use of the Ba:Ca ratio in the otoliths may provide a more accurate classification of estuarine habitat use than the Sr:Ca ratio (Elsdon, Gillanders, 2005; Tanner et al., 2013; Gillanders et al., 2015).

The significantly higher $\mathrm{Ba}: \mathrm{Ca}$ ratios at the edges of the otoliths of larger specimens of M. liza $\left(1.58 \pm 1.23 \mu \mathrm{mol}^{\mathrm{mol}} \mathrm{mol}^{-}\right.$ $\left.{ }^{1}\right)$ suggest a preference for areas with lower salinity. On the other hand, the high Sr:Ca ratios $\left(2.6 \pm 2.9 \mathrm{mmol}_{\mathrm{mol}}{ }^{-1}\right)$ and the low $\mathrm{Ba}: \mathrm{Ca}$ ratios at the edges of the otoliths $(0.24 \pm 0.25$ $\mu$ mol.mol ${ }^{-1}$ ) of $M$. curema suggest a preference for areas with higher salinities. These findings, in association with the reproductive and recruitment patterns of both species, support our hypothesis of different habitat utilization of $M$. curema and M. liza in the rio Tramandaí Estuary.

These characteristics reveal that $M$. curema is a marine species that regularly enters estuaries in substantial numbers, particularly as juveniles, but use nearshore marine waters as alternative habitats to varying degrees. In Mexican coastal waters, báñez-Aguirre et al. (2012) found that M. curema has a more diverse euryhaline preference than the simple catadromous behavior. In Venezuela lagoons, M. curema has four different cohorts, reflecting different ages and different life stages coexisting in the same habitat (Marin et al., 2003). In Pernambuco, Brazil, two habitat use behaviors for M. curema were described, as some juveniles appear to use waters of high salinity and others seem to inhabit lowsalinity waters (Silva, 2007).

Fortunato et al. (2017) suggested three patterns of estuarine use by $M$. liza during most of their lifetime based on individuals sampled at several different locations in Paranaguá Bay, Brazil; Samborombón Bay, Mar Chiquita Coastal Lagoon; and San Blas, Argentina. Type I corresponds to the regular use of estuarine habitat; Type II corresponds to a fluctuating pattern of estuarine and sea (high salinity waters) habitat use; and Type III corresponds to a high preference for saline water. Our results agree with Fortunato et al. (2017), as M. liza also showed a high variability of migratory patterns in the rio Tramandaí Estuary. These characteristics reveal a marine species that require sheltered estuarine habitats as juveniles but live along coastal areas where there are no such habitats; thus, these species are dependent on the habitats of that type that are present in estuaries.

In conclusion, based on otolith microelement analysis, both M. curema and M. liza can be classified in as Marine Migrants sensu Elliott et al. (2007). However, considering the habitat use by juveniles, both species may be classified into two different subcategories: $M$. curema as a Marine Estuarine-opportunist and M. liza as an Estuarine Dependent in the rio Tramandaí River Estuary. This important distinction in the life cycles of these two species is fundamental for developing conservation strategies for these fishery resources. Considering that estuary habitats suffer from greater anthropic impacts than surf-zone coastal areas, it seems that $M$. liza is much more vulnerable than $M$. curema in terms of estuarine habitat conservation (Barletta et al., 2010).

\section{Acknowledgments}

We thank the artisanal fishermen from rio Tramandaí for the availability of the M. liza and M. curema individuals. This work was benefited from finantial support provided by the Fundação de Amparo à pesquisa do Estado do Rio Grande do Sul - FAPERGS (process 2327-2551/14-6), and Conselho Nacional de Desenvolvimento Científico e Tecnológico CNPq Brazilian Long Term Ecological Research Program - PELD (process 403805/2012-0). Valéria Marques Lemos currently has postdoctoral fellowship from the Coordenação de Aperfeiçoamento de Pessoal de Nível Superior - CAPES (process A101/2013) and João Paes Vieira received a grant from CNPq (process 482236/2011-6).

\section{References}

Albieri RJ, Araújo FG. Reproductive biology of the mullet Mugil liza (Teleostei: Mugilidae) in a tropical Brazilian bay. Zoologia. 2010; 27(3):331-40. Available from: http://dx.doi.org/10.1590/ S1984-46702010000300003

Albieri RJ, Araújo FG, Uehara W. Differences in reproductive strategies between two co-occurring mullets Mugil curema Valenciennes 1836 and Mugil liza Valenciennes 1836 (Mugilidae) in a tropical bay. Trop Zool. 2010; 23(1):51-62.

Avigliano E, Callicó-Fortunato R, Buitrago J, Volpedo AV. Is otolith microchemistry ( $\mathrm{Sr}: \mathrm{Ca}$ and $\mathrm{Ba}: \mathrm{Ca}$ ratios) useful to identify Mugil curema populations in the Southeastern Caribbean Sea? Braz J Biol. 2015; 75(4 Suppl.1):S45-S51. Available from: http://dx.doi.org/10.1590/1519-6984.01014

Barletta M, Jaureguizar AJ, Baigun C, Fontoura NF, Agostinho AA, Almeida-Val VMF, Val AL, Torres RA, Jimenes-Segura LF, Giarrizzo T, Fabré NN, Batista VS, Lasso C, Taphorn DC, Costa MF, Chaves PT, Vieira JP, Corrêa MFM. Fish and aquatic habitat conservation in South America: a continental overview with emphasis on neotropical systems. J Fish Biol. 2010; 76(9): 2118-76. Available from: http://dx.doi.org/10.1111/j.10958649.2010.02684.x 
Blaber SJM, Blaber TG. Factors affecting the distribution of juvenile estuarine and inshore fish. J Fish Biol. 1980; 17(2):143-62. Available from: http://dx.doi.org/10.1111/j.1095-8649.1980. tb02749.x

Chang CW, Iizuka Y, Tzeng WN. Migratory environmental history of the grey mullet Mugil cephalus as revealed by otolith $\mathrm{Sr}: \mathrm{Ca}$ ratios. Mar Ecol Prog Ser. 2004; 269:277-88.

Chang CW, Iizuka Y. Estuarine use and movement patterns of seven sympatric Mugilidae fishes: the Tatu Creek estuary, central western Taiwan. Estuar Coast Shelf Sci. 2012; 106:121-26. Available from: http://dx.doi.org/10.1016/j.ecss.2012.04.023

Ciotti AM, Odebrecht C, Fillmann G, Möller OO. Freshwater outflow and Subtropical Convergence influence on phytoplankton biomass on the southern Brazilian continental shelf. Cont Shelf Res. 1995; 15(14):1737-56.

Elliott M, Whitfield AK, Potter IC, Blaber SJM, Cyrus DP, Nordlie FG, Harrison TD. The guild approach to categorizing estuarine fish assemblages: a global review. Fish Fish. 2007; 8(3):241-68. Available from: http://dx.doi.org/10.1111/j.14672679.2007.00253.x

Elsdon TS, Gillanders BM. Alternative life-history patterns of estuarine fish: barium in otoliths elucidates freshwater residency. Can J Fish Aquat Sci. 2005; 62(5):1143-52. Available from: http://dx.doi.org/10.1139/f05-029

Fernandez WS, Dias JF. Aspects of the reproduction of Mugil curema Valenciennes, 1836 in two coastal systems in southeastern Brazil. Trop Zool. 2013; 26(1):15-32. Available from: http://dx.doi.org/10.1080/03946975.2013.775052

Fortunato RC, González-Castro M, Galán AR, Alonso IG, Kunert C, Durà VB, Volpedo A. Identification of potential fish stocks and lifetime movement patterns of Mugil liza Valenciennes 1836 in the Southwestern Atlantic Ocean. Fish Res. 2017; 193:164-72. Available from: http://dx.doi.org/10.1016/j. fishres.2017.04.005

Gillanders BM. Otolith chemistry to determine movements of diadromous and freshwater fish. Aquat Living Resour. 2005; 18(3):291-300. Available from: http://dx.doi.org/10.1051/ alr:2005033

Gillanders BM, Izzo C, Doubleday ZA, Ye Q. Partial migration: growth varies between resident and migratory fish. Biol Lett. 2015; 11(3):20140850 [5p.]. Available from: http://dx.doi. org/10.1098/rsbl.2014.0850

Ibáñez-Aguirre $\mathrm{AL}$, Chang $\mathrm{CW}$, Hsu $\mathrm{CC}$, Wang $\mathrm{CH}$, Iizuka $\mathrm{Y}$, Tzeng WN. Diversity of migratory environmental history of the mullets Mugil cephalus and M. curema in Mexican coastal waters as indicated by otolith Sr:Ca ratios. Cienc Mar. 2012; 38(1A):73-87.

Ibáñez-Aguirre AL. Coexistence of Mugil cephalus and $M$. curema in a coastal lagoon in the Gulf of Mexico. J Fish Biol. 1993; 42(6):959-61. Available from: http://dx.doi. org/10.1111/j.1095-8649.1993.tb00401.x

Ibáñez-Aguirre AL, Gallardo-Cabello M. Reproduction of Mugil cephalus and M. curema (Pisces: Mugilidae) from a coastal lagoon in the Gulf of Mexico. Bull Mar Sci. 2004; 75(1):37-49.
Kapusta SC, Bemvenuti CE, Würdig NL. Meiofauna spatialtemporal distribution in a subtropical estuary of Southern Coast Brazil. J Coast Res. 2006; 39(2):1238-42.

Kraus RT, Secor DH. Incorporation of strontium into otoliths of an estuarine fish. J Exp Mar Biol Ecol. 2004; 302(1):85-106.

Lemos VM, Varela AS, Schwingel PR, Muelbert JH, Vieira JP. Migration and reproductive biology of Mugil liza (Teleostei: Mugilidae) in south Brazil. J Fish Biol. 2014; 85(3):671-87. Available from: http://dx.doi.org/10.1111/jfb.12452

Marin E, Baumar J, Quintero A, Bussiere D, Dodson JJ. Reproduction and recruitment of white mullet (Mugil curema) to a tropical lagoon (Margarita Island, Venezuela) as revealed by otolith microstructure. Fish Bull. 2003; 101(4):809-21.

Menezes NA, Nirchio M, Oliveira C, Siccha-Ramirez R. Taxonomic review of the species of Mugil (Teleostei: Perciformes: Mugilidae) from the Atlantic South Caribbean and South America, with integration of morphological, cytogenetic and molecular data. Zootaxa 2015; 3918(1):1-38. Available from: http://dx.doi.org/10.11646/zootaxa.3918.1.1

Möller OO, Piola AR, Freitas AC, Campos EJD. The effects of river discharge and seasonal winds on the shelf off southeastern South America. Cont Shelf Res. 2008; 28(13):1607-24.

Ramos LA, Vieira JP. Composição específica e abundância de peixes de zonas rasas dos cinco estuários do Rio Grande do Sul, Brasil. Bol Inst Pesca. 2001; 27(1):109-21.

Silva FMS. Biologie, pêche et dynamique de la population de Mulet Blanc (Mugil curema, Valenciennes, 1836) de Pernambuco, Brésil. [PhD Thesis]. Quimper: Universite de Bretagne Occidentale; 2007.

Silva SS. Biology of juvenile grey mullet: a short review. Aquaculture. 1980; 19(1):21-36.

Soares I, Möller OO. Low-frequency currents and water spatial mass distribution on the southern Brazilian shelf. Cont Shelf Res. 2001; 21(16-17):1785-814.

Tanner SE, Reis-Santos P, Vasconcelos RP, Fonseca VF, França S, Cabral HN, Thorrold SR. Does otolith geochemistry record ambient environmental conditions in a temperate tidal estuary? J Exp Mar Biol Ecol. 2013; 441(1):7-15.

Vieira JP. Juvenile mullets (Pisces: Mugilidae) in the estuary of Lagoa dos Patos, RS, Brazil. Copeia. 1991; 1991(2):409-18. Available from: http://dx.doi.org/10.2307/1446590

Walther BD, Limburg KE. The use of otolith chemistry to characterize diadromous migrations. J Fish Biol. 2012; 81(2):796-825. Available from: http://dx.doi.org/10.1111/ j.1095-8649.2012.03371.x

Wang $\mathrm{CH}$. Otolith elemental ratios of flathead mullet Mugil cephalus in Taiwanese waters reveal variable patterns of habitat use. Estuar Coast Shelf Sci. 2014; 151:124-30. Available from: https://doi.org/10.1016/j.ecss.2014.08.024 